\title{
CLINICAL STUDY OF CHRONIC ULCERS OF THE LEG
}

\author{
D. G. Umeshchandraํ, Vinayak Ingalalli ${ }^{2}$ \\ 1 Professor, Department of Surgery, Mahadevappa Rampure Medical College. \\ 2Postgraduate Student, Department of Surgery, Mahadevappa Rampure Medical College.
}

\section{ABSTRACT}

\section{BACKGROUND}

Chronic ulceration of the lower leg is a frequent condition, with a prevalence in the population over 60 years of age. The incidence of ulceration is rising as a result of the ageing population and increased risk factors for atherosclerotic occlusion such as smoking, obesity and diabetes. For a proper treatment of patients with leg ulcers, it is important to be aware of the large differential diagnosis of leg ulceration and to effectively manage the conditions.

Aims and Objectives - The main objective of the study was to analyse the incidence of different types of chronic leg ulcers, risk factors and their management.

\section{MATERIALS AND METHODS}

Prospective study of 200 cases of chronic leg ulcers admitted at Basaveshwara Teaching and Hospital, Kalaburagi during the period September 2014 to September 2016.

\section{RESULTS}

In a study group of 200 cases, the most common type of ulcer was found to be diabetic ulcer and the most common age group was $>51$ years with male predominance.

\section{CONCLUSION}

In a study group of 200 cases, most of the patients with leg ulcers had an underlined systemic disease such as diabetes mellitus, venous valvular insufficiency, arterial occlusion secondary to atherosclerosis, leprosy and malignancy.

\section{KEYWORDS}

Chronic Nonhealing Ulcer, Diabetic Leg and Foot Ulcer, Varicose Ulcer, Trophic Ulcer, Arterial Ulcer, Malignant Ulcer, Traumatic Ulcer.

HOW TO CITE THIS ARTICLE: Umeshchandra DG, Ingalalli V. Clinical study of chronic ulcers of the leg. J. Evolution Med. Dent. Sci. 2016;5(100):7370-7373, DOI: 10. 14260/jemds/2016/1668

\section{BACKGROUND}

Chronic ulceration of the lower leg and foot is a frequent condition and wide in distribution. They may be associated with a number of medical, surgical \& dermatological conditions, the patient suffering is very immense, commonly seen in most of the surgical wards and OPD. The ulcer is said to be chronic when it persists for more than 6 weeks and shows no tendency to heal after three or more months, the slow healing tendency is not simply explained by depth and size, but caused by an underlying pathologic factor that needs to be removed to induce healing.

The problems of leg ulcer represent a wide spectrum of aetiology, pathology, severity and morbidity. The main causes are venous valve insufficiency, lower extremity arterial disease and diabetes. Less frequent conditions are infections, vasculitides, skin malignancies and ulcerating skin diseases such as pyoderma gangrenosum.

Financial or Other, Competing Interest: None.

Submission 09-11-2016, Peer Review 01-12-2016,

Acceptance 09-12-2016, Published 15-12-2016.

Corresponding Author:

Dr. Vinayak Ingalalli,

Room No. 213,

PG Boys Hostel,

BTGH, Sedam Road,

Kalaburagi.

E-mail:ingalalli@gmail.com

DOI: $10.14260 /$ jemds $/ 2016 / 1668$

(c) $(i) \subseteq$
But even rare condition exists such as recently discovered combination of vasculitides and hypercoagulability. For proper treatment of the patient with leg ulcers, it is important to be aware of the large differential diagnosis of leg ulceration. The causes may be various but the anatomical situation of ulcers in the leg by itself can give rise to problems that can at times test the ingenuity and patience of the surgeons.

During the past few decades, considerable knowledge has been gained regarding the physiology, anatomy, pathology and management of chronic leg ulcers. Despite all this the management of chronic leg ulcers is a fertile field for experimentation.

\section{Aims and Objectives}

- To compare and analyse the distribution of age, sex, systemic disease and location of the ulcer among 200 cases of the study group.

- To study the clinical features of various types of leg ulcers.

- To study the usefulness of applied investigations.

- To effectively manage the condition.

- To prevent leg ulceration as far as possible in high-risk individuals prone to the condition.

\section{MATERIALS AND METHODS}

The material for this study was drawn from patients admitted to the Surgical Department, Basaveshwara Teaching and General Hospital, Kalaburagi. A total number of 200 cases were considered for this study. This group was a diversified one and 


\section{Jemds.com}

included patients of both sexes and of all ages from 12 years and above, all religion and economic strata.

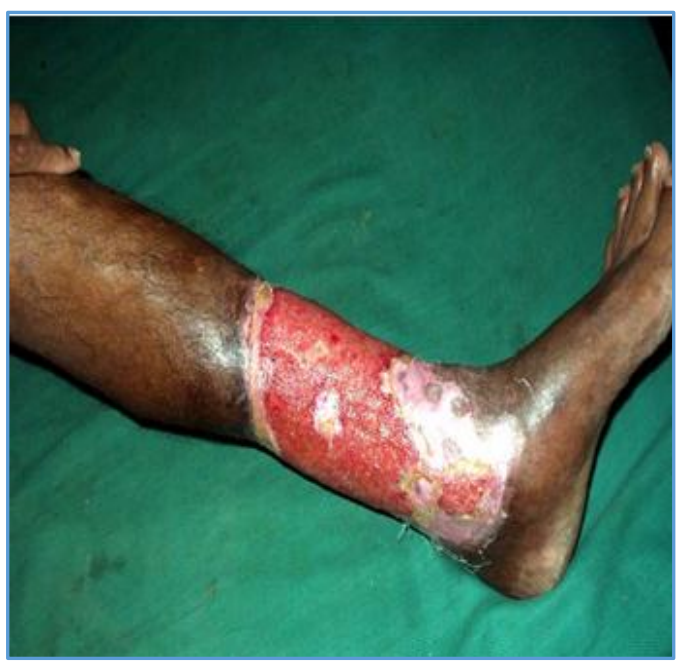

Figure 1. Venous Ulcer

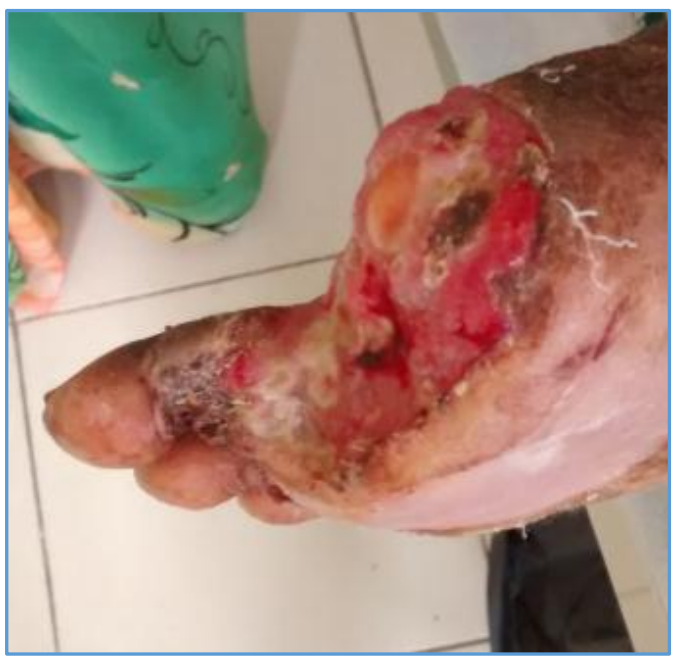

Figure 2. Diabetic Ulcer

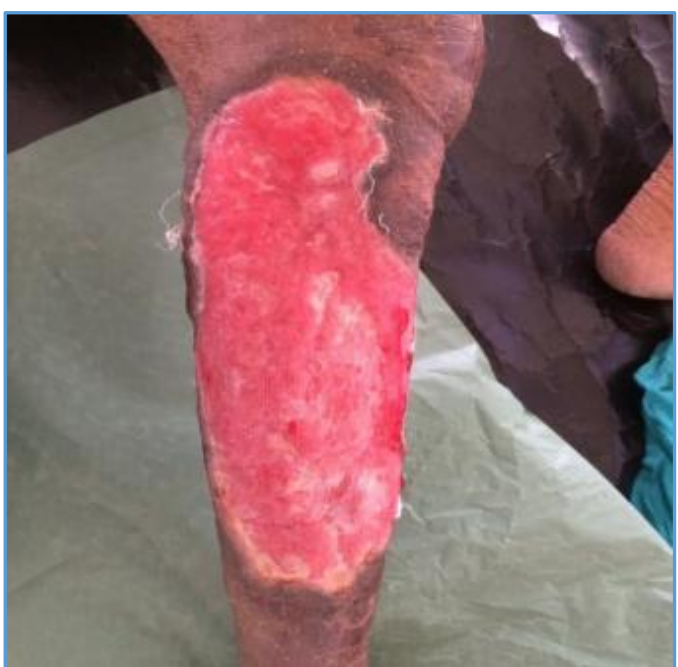

Figure 3. Traumatic Ulcer

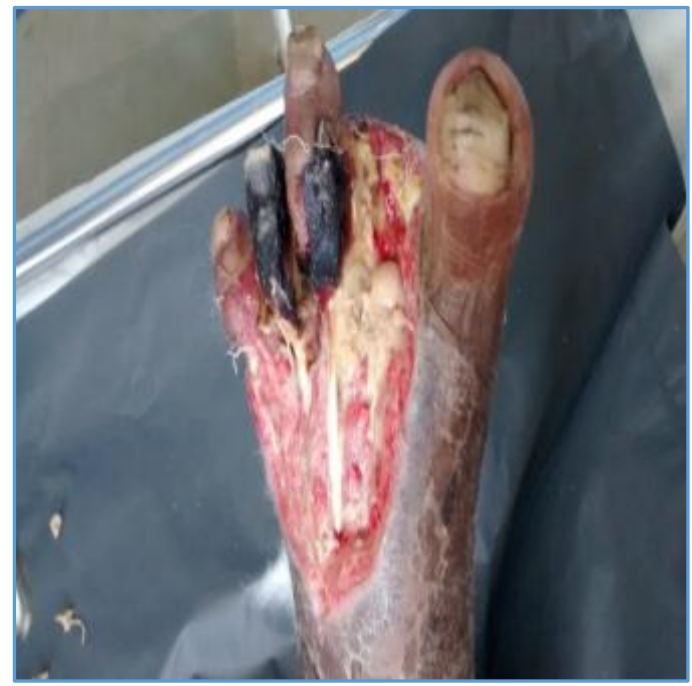

Figure 4. Arterial Ulcer

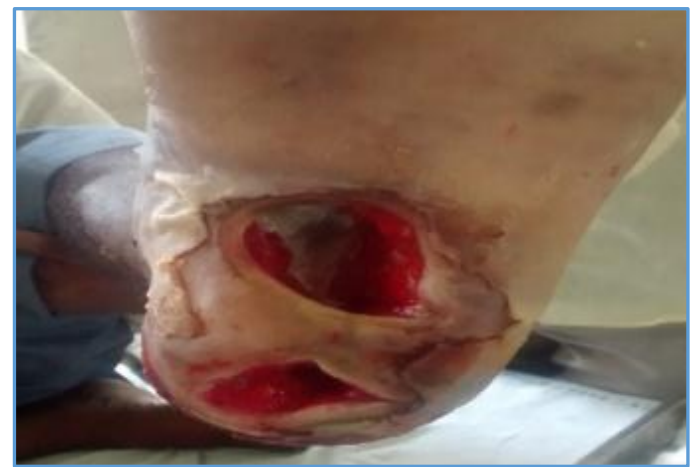

Figure 5. Trophic Ulcer

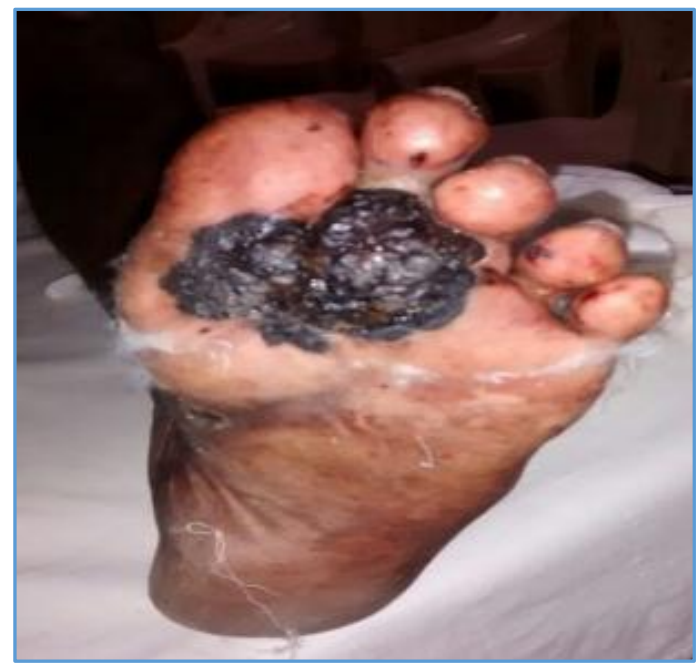

Figure 6. Malignant Ulcer

\section{RESULTS AND DISCUSSION}

Chronic leg ulcer is a common cause of morbidity, and its prevalence in the community ranges from $1.9 \%$ to $13.1 \% .^{1}$ There are few Indian studies on the epidemiology of chronic wounds, one study estimated the prevalence at 4.5 per 1000 population. The incidence of acute wounds was more than double at 10.5 per 1000 population. $^{2}$ 


\begin{tabular}{|c|c|c|c|}
\hline $\begin{array}{c}\text { Sl. } \\
\text { No. }\end{array}$ & $\begin{array}{c}\text { Etiological } \\
\text { Type }\end{array}$ & $\begin{array}{c}\text { No. of } \\
\text { Patients }\end{array}$ & $\begin{array}{c}\text { Percentage } \\
\text { (\%) }\end{array}$ \\
\hline 1. & Diabetic ulcer & 84 & $42 \%$ \\
\hline 2. & Traumatic ulcer & 50 & $25 \%$ \\
\hline 3. & Arterial ulcer & 34 & $17 \%$ \\
\hline 4. & Venous ulcer & 25 & $12.5 \%$ \\
\hline 5. & Trophic ulcer & 5 & $2.5 \%$ \\
\hline 6. & Malignant ulcer & 2 & $1 \%$ \\
\hline \multicolumn{3}{|c|}{ Table 1. Distribution of Various } \\
types of Chronic Leg Ulcers \\
\hline
\end{tabular}

Total No. of patients studied- 200.

Among all chronic wounds, lower extremity venous ulcer dominates the differential diagnosis accounting for up to $90 \%$ of the cases (Burton S. Claude), ${ }^{3}$ (Callum M. J. et al). ${ }^{4}$ Arterial diseases account for $5 \%$ to $10 \%$, most others are due to neuropathy or a combination of both (Yound J. R). ${ }^{5}$ In this study, chronic ulcer with vascular aetiology accounted for only $29.5 \%$ of all chronic ulcers. Out of this, arterial ulcers accounted for $17 \%$ and venous ulcers accounted for $12.5 \%$. Chronic ulcers associated with diabetes accounted for nearly $42 \%$. Traumatic ulcers accounted for $25 \%$ of the cases. Malignant ulcers accounted for $1 \%$ and trophic ulcers for $2.5 \%$.

In our study, there were more men $(82.5 \%)$ than women $(17.5 \%)$ with leg and foot ulcers. However, no differences between sexes were found when age specific relative frequencies for all ulcers were compared.

\begin{tabular}{|c|c|c|c|}
\hline Sl. No. & Age Group & No. of Cases & Percentage \\
\hline 1 & $12-20$ & 2 & $1 \%$ \\
\hline 2 & $21-30$ & 11 & $5.5 \%$ \\
\hline 3 & $31-40$ & 48 & $24 \%$ \\
\hline 4 & $41-50$ & 66 & $33 \%$ \\
\hline 5 & 51 and above & 73 & $36.5 \%$ \\
\hline \multicolumn{3}{|c|}{ Table 2. Age Distribution of Various } \\
types of Chronic Leg Ulcers \\
\hline
\end{tabular}

Incidences of leg ulcers in this study group were found to be maximum in the age group of $51 \&$ above. Hence, the patients of age group 0-12 years were not included in this study.

The youngest patient was 19 years old and the oldest was 80 years old. Cornwill et al ${ }^{6}$ in their study had $70 \%$ of the patients over the age of 70 years and according to a study done by Callam MJ ulceration began before the age of 40 years in $22 \%$ of the patients.

\begin{tabular}{|c|c|c|c|c|c|}
\hline $\begin{array}{c}\text { Sl. } \\
\text { No. }\end{array}$ & $\begin{array}{c}\text { Type of } \\
\text { Ulcer }\end{array}$ & $\begin{array}{c}\text { Gaiter } \\
\text { Zone }\end{array}$ & Foot & Leg & Total \\
\hline 1 & $\begin{array}{c}\text { Diabetic } \\
\text { ulcer }\end{array}$ & 0 & $\begin{array}{c}78 \\
(92.85 \%)\end{array}$ & $\begin{array}{c}6 \\
(7.15 \%)\end{array}$ & 84 \\
\hline 2 & $\begin{array}{c}\text { Traumatic } \\
\text { ulcer }\end{array}$ & 0 & $\begin{array}{c}36 \\
(72 \%)\end{array}$ & $\begin{array}{c}14 \\
(28 \%)\end{array}$ & 50 \\
\hline 3 & $\begin{array}{c}\text { Arterial } \\
\text { ulcer }\end{array}$ & 0 & $\begin{array}{c}34 \\
(100 \%)\end{array}$ & 0 & 34 \\
\hline 4 & $\begin{array}{c}\text { Venous } \\
\text { ulcer }\end{array}$ & $\begin{array}{c}23 \\
(92 \%)\end{array}$ & 0 & $\begin{array}{c}2 \\
(8 \%)\end{array}$ & 25 \\
\hline 5 & $\begin{array}{c}\text { Trophic } \\
\text { ulcer }\end{array}$ & 0 & $\begin{array}{c}5 \\
(100 \%)\end{array}$ & 0 & 5 \\
\hline 6 & $\begin{array}{c}\text { Malignant } \\
\text { ulcer }\end{array}$ & 0 & $\begin{array}{c}2 \\
(100 \%)\end{array}$ & 0 & 2 \\
\hline \multicolumn{7}{|c|}{ Table 3. Location of the Ulcer according to its Types } \\
\hline
\end{tabular}

J. Evolution Med. Dent. Sci./eISSN- 2278-4802, pISSN- 2278-4748/ Vol. 5/ Issue 100/ Dec. 15, 2016
According to Hanson Carita, ${ }^{7}$ ulcers below the line of shoe and feet are mostly caused by arterial insufficiency and or diabetes. Ulcers on the gaiter zone are mostly caused by venous insufficiency. In our study, the venous ulcers occurred more commonly in the gaiter zone $(92 \%)$. Whereas arterial and diabetic ulcers occurred mainly in the foot i.e., $100 \%$ and $92.85 \%$ respectively.

Out of 200 cases, pus for culture and sensitivity was sent in 156 cases. Staphylococcus was found to be the most common pathogen in 46 cases. This was followed by Proteus, in 30 cases. Most of the patients in this study group belong to the lower socioeconomic status.

\begin{tabular}{|c|c|c|}
\hline Sl. No. & Pathogen & No. of Cases \\
\hline 1 & Staphylococcus & 46 \\
\hline 2 & Streptococcus & 20 \\
\hline 3 & Klebsiella & 28 \\
\hline 4 & Proteus & 24 \\
\hline 5 & E coli & 30 \\
\hline 6 & Pseudomonas & 2 \\
\hline 7 & No growth & 6 \\
\hline \multicolumn{2}{|c|}{ Table 4. Types of Bacteria Isolated from the Ulcers } \\
\hline
\end{tabular}

All the wounds were thoroughly debrided multiple times and treated with antibiotics according to sensitivity, and the underlying causes were treated accordingly. For diabetics, insulin therapy was started with blood sugar monitoring. Patients who had venous ulcers wore elastic crepe bandages stretched to $50 \%$ providing of around $14 \mathrm{mmHg}$ compression pressure under one layer and were also subjected to local dressings and Bisgard's line of management, and once the ulcers were healed the patients were called back for surgery for varicose veins. Arterial ulcers were treated with Pentoxifylline, statins and regular dressings were done. Gangrenous digits were disarticulated and amputation was performed according to the Doppler reports in patients who had no other options. Traumatic and trophic ulcers were treated with regular dressings and antibiotics. Malignant ulcers were treated with wide local excision.

All the small ulcers were managed with regular dressings which healed with secondary intention and others were treated with secondary suturing. All the large ulcers were prepared for skin grafting, the wound was prepared with vacuum dressings ${ }^{8}$, use of Eptoin ${ }^{9}$ and capsules of colostrum extract, ${ }^{10}$ when the ulcer bed was ready split skin grafting was done.

\section{CONCLUSIONS}

The highest age incidence of leg and foot ulcers in this study was in the age group of 51 years and above (36.5\%). The median age was 45 years and the mean age was 44.28 years. There was a marked male predominance of $82.5 \%$. Foot was the most commonly affected region $(77.5 \%) .92 \%$ of venous ulcers were situated in the gaiter zone. $92.8 \%$ of diabetic ulcers were situated in the foot. $100 \%$ of the arterial ulcers were situated in the foot. Staphylococcus was found to be the most common pathogen to be isolated from the ulcers. Patients with leg ulceration who had gangrene, underwent amputation as a lifesaving procedure. Patients with malignant ulcer underwent wide local excision. Most patients with varicose 
veins underwent some form of operation i.e., ligation and stripping and or Trendelenburg operation and subfascial ligation following healing of ulcers. Patients with large traumatic ulcers underwent skin grafting.

\section{REFERENCES}

1. Rayner R, Carville K, Keaton J, et al. Leg ulcers: atypical presentations and associated co-morbidities. Wound Practice and Research 2009;17(4):168-85.

2. Shukla VK, Ansari MA, Gupta SK. Wound healing research: a perspective from India. International Journal of Lower Extremity Wounds 2005;4(1):7-8.

3. Burton CS. Treatment of leg ulcers. Dermatol Clin 1993;11(2):315-23.

4. Callam MJ, Harper DR, Dale JJ, et al. Chronic ulcers of the leg: clinical history. Br Med J 1987;294(6584):1389-91.
5. Young JR. Differential diagnosis of leg ulcers. Cardiovasc Clin 1983;13(2):171-93.

6. Cornwall JV, Dore CJ, Lewis JD. Leg ulcers-epidemiology and etiology. Br J Surg 1986;73(9):693-6.

7. Hansson C. Studies on leg and foot ulcers. Acta Derm Venereol Suppl 1988;136:1-45.

8. Eldad A, Tzur T. Vaccum-a novel method for treating chronic wounds. Harefuah 2003;142(12):834-6, 878, 877.

9. Bhatia A, Prakash S. Topical phenytoin for wound healing. Dermatology Online Journal 2004;10(1):5.

10. Kshirsagar AY, Vekariya MA, Gupta V, et al. A comparative study of colostrum dressing versus conventional dressing in deep wounds. Journal of Clinical and Diagnostic Research 2015;9(4):PC01-4. 